\title{
Obituaries
}

\section{Sir Boris Uvarov}

THE death of Sir Boris Uvarov, KCMG, DSe, FRS, on March 18, aged 82, has deprived the scienco of entomology of one of its most eminent men. Bost known as a taxonomist-for his description of some 900 new species and 218 now genera, and an ecologist-for his work on the phaso theory of locusts, insects and climatc, and arid zone entomology, he will also be remembered as the chief founder of international coopcration in locust research and control, and as a pioneer in the biogeographical studies of locusts, forming the scientific basis for the foundation of many international organizations.

Boris Potrovitch Uvarov was born in 1888 at Uralsk in Russia and obtained a first class degree in biology in 1910 at the University of St Petersburg. 'There followed a period of work in several provincial departments of agricultur' and in 1915 at the age of 27 he was made director of the Tiflis Bureau of Plant Protection. He was already an authority on the Orthoptera of Central Asia and had become interested in locusts and their control; in 1919 he was appointed keeper of entomology and zoology in the State Museum and reader in entomology at the University of Georgia, and in 1921 published his famous paper propounding the phase theory of locusts. He was always punctilious in sharing the diseovery of locust phases with Fauré, the South African entomologist, but Uvarov's name is universally associated with the theory, not only because he went on to develop it furthor but because of the practical use he made of it.

The practical opportunity came when he joined the Imperial Bureau of Entomology (now the Commonwealth Institute of Entomology) in London, whero ho remained from 1920 to 1945; the British government was concerned about locust invasions of the African colonies and Uvarov was the obvious man to consult. He suggested a programme of extensive ficld surveys in Africa to map the seasonal distribution of locusts, with ecological and biogeographical analysis in London. The results of this work, pursued over several years and interpreted in the light of the phase theory, revealed permanent outbreak areas for both the migratory and the red locust. Uvarov and others had also pointed out that cooperation between the affected countries was utterly essential for locust control, and a scries of international conferences was held to promote this view, leading to proposals for international organizations in Africa to control the African migratory and red locusts in their outbreak areas. P'rogress was interrupted by the 1939-45 war, when the protection of strategic food supplies became vital; Uvarov helped to create the Middle East Anti-Locust Unit on a para-military basis to carry out control campaigns in many countries.

After the war, because of the threat of locusts to overseas agriculture, the Colonial Office set up the AntiLocust Research Centre as an independent research institute, with Uvarov as director. Uvarov here continued his untiring effort against locusts; the basis of the Centre's work was then, and still remains, the view that officient locust control is possible only with a background knowledge of the biology, biogeography and behaviour of the species.

The demands of administration had not diminished Uvarov's other interests; ho was a world authority on the taxonomy, systematics and biology of Acrididae and in 1928 ho had published Locusts and Grasshoppers, a lucid review of the whole field. His interest in ecology led to the publication in 1931 of Insects and Climate, which stimulated interest in a neglected field.

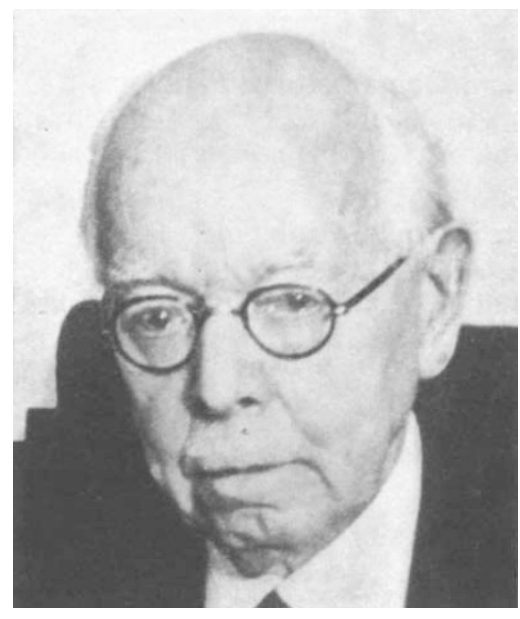

In the 1940s and 50s Uvarov travelled widely, visiting at least twenty-three countries at the invitation of governments and international organizations and, because of his encyclopaedic knowledge of the subject, he was able to make far-reaching suggestions for locust rescarch and control. The international organizations for controlling the African migratory and rod locusts were established and, since then, no plagucs of these species have appeared a striking proof of the validity of Uvarov's theories and their practical significance. Studies of the desert locust, howcver, showed that its outbreak areas were not restricted; it had an invasion area covering more than fifty countrics. Uvarov saw that special coordination was necessary and interested the Food and Agriculture Organization of the United Nations which, in 1953, undertook the international coordination of control campaigns against the desert locust. Uvarov was appointed consultant to the FAO Technical Advisory Committee and was to play a major part, particularly as chairman of the FAO Panel of Experts on the Long-Term Policy for Desert Locust Control in 1956. He also helped to initiate the UNDP/FAO Desert Locust Project, the largest single project ever supported by the UNDP.

In 1959 he retired as director of the ALRC but remained a consultant, and began a new book on grasshoppers and locusts; he was as active as ever and, in 1959, toured Australia at the invitation of the CSTRO to give advice about the Australian plague locust, leading eventually to a large collaborative research project between CSIRO and the ALRC which is still in progress. He had long been a member of the UNESCO Arid Zone Committee and now began to explore a new field, expressed in a series of important papers on arid zone entomology and the entomological problems of agriculture in developing countries, Vol. 1 of Grasshoppers and Locusts was published in 1966 and ho was working on Vol. 2 until shortly before his death.

Uvarov recoived many medals, awards and public honours; he was elected to the Royal Society in 1950 and knighted in 1961. He was a man of great strength and integrity of character, coupled with simplicity and humility. Sornctimes he had a sharp tonguc but it was tempered with a dry sense of humour; above all, ho was always ready to help his fellow scientists in any way he could. He would wish nothing better for his memorial than that the work he began and fostered should continue and expand. 